\title{
Characterization of Calcium Oxide in Root Perforation Sealer Materials
}

\author{
Carlos ESTRELA ${ }^{1}$ \\ Manoel Damião SOUSA-NETO ${ }^{3}$ \\ Orlando Aguirre GUEDES ${ }^{1}$ \\ Ana Helena Gonçalves ALENCAR ${ }^{1}$ \\ Marco Antonio Hungaro DUARTE ${ }^{2}$ \\ Jesus Djalma PÉCORA ${ }^{3}$ \\ ${ }^{1}$ Dental School, UFG - Federal University of Goiás, Goiânia, GO, Brazil \\ ${ }^{2}$ Bauru Dental School, USP - University of São Paulo, Bauru, SP, Brazil \\ ${ }^{3}$ Ribeirão Preto Dental School, University of São Paulo, Ribeirão Preto, SP, Brazil
}

\begin{abstract}
Root perforation represents an undesirable complication that may lead to an unfavorable prognosis. The aims of this study were to characterize and to compare the presence of calcium oxide $(\mathrm{CaO})$ on the chemical composition of materials used for root perforation therapy: gray and white mineral trioxide aggregate (MTA) and Portland cement (PC), gray $\mathrm{MTA}+5 \% \mathrm{CaO}$ and gray $\mathrm{MTA}+10 \% \mathrm{CaO}$. The last two materials were analyzed to evaluate the increase of $\mathrm{CaO}$ in the final sample. $\mathrm{CaO}$ alone was used as a standard. Eighteen polyethylene tubes with an internal diameter of $3 \mathrm{~mm}$ and $3 \mathrm{~mm}$ in length were prepared, filled and then transferred to a chamber with $95 \%$ relative humidity and a temperature of $37^{\circ} \mathrm{C}$. The chemical compounds (particularly $\mathrm{CaO}$ ) and the main components were analyzed by energy-dispersive X-ray microanalysis (EDX). EDX revealed the following concentrations of CaO: gray MTA: 59.28\%, white MTA: $63.09 \%$; PC: $72.51 \%$; gray MTA+5\% $\mathrm{CaO}: 63.48 \%$ and gray $\mathrm{MTA}+10 \% \mathrm{CaO}: 67.55 \%$. The tested materials presented different concentrations of $\mathrm{CaO}$. Even with an increase of 5 and $10 \% \mathrm{CaO}$ in gray MTA, the CaO levels found in the MTA samples were lower than those found in PC.
\end{abstract}

Key Words: MTA, Portland cement, calcium oxide, calcium hydroxide, root perforations.

\section{INTRODUCTION}

Root canal perforation is a pathological or technical accident that results in an artificial communication between the pulp cavity and the periodontal tissues, capable of affecting the prognosis of endodontic treatment. Different materials have been studied and proposed to seal root perforations $(1,2)$, and the biological responses have focused on materials with capacity of stimulating tissue mineralization, such as calcium hydroxide $(\mathrm{CH})$, and mineral trioxide aggregate (MTA) (1-4).

The capacity of MTA to properly seal communications between the tooth and the external surfaces has been demonstrated $(5,6)$. This material has been evaluated in a series of in vivo and in vitro investigations that reported good sealing ability and tissue behavior (5-7). In a well-known study (3), $\mathrm{CH}$ and MTA were inserted into dentin cylinders, implanted in the subcutaneous tissue of rats and analyzed by polarized light and Von Kossa staining for calcium salts. $\mathrm{CH}$ showed formation of calcite granulations birefringent to the polarized light near the tube lumen. Under these granulations, a Von Kossa positive bridge of hard tissue was formed. Furthermore, the presence of calcite granulations birefringent to the polarized light was also observed inside the dentinal tubules. With MTA, the same situation was observed, but with a slightly smaller number of calcite granulations than that observed with $\mathrm{CH}$. These granulations were in contact with the test material, which did not occur with $\mathrm{CH}$. Thus, the mechanism of action of MTA is probably the same as that of $\mathrm{CH}$. It has also been shown that Portland cement (PC) contains the same main chemical elements

Correspondence: Prof. Dr. Carlos Estrela, Universidade Federal de Goiás, Department of Stomatologic Sciences, Praça Universitária S/N, Setor Universitário, 74605-220 Goiânia, GO, Brasil. Tel/Fax: +55-62-3209-6254. e-mail: estrela3@terra.com.br 
of MTA, except that MTA also contains bismuth (8). Important studies about constituents and properties of PC and MTA have been discussed (7). Camilleri et al. (9) also verified that commercial versions of MTA were shown to have similar constitution to ordinary PC, except for the addition of bismuth compounds. The mechanism of action of MTA and PC, stimulating hard tissue deposition, has some similarity to that of $\mathrm{CH}(10)$. The healing process of intentional lateral root perforation repaired using MTA in dogs' teeth was evaluated (2). The results showed no inflammation and deposition of cementum over MTA in the majority of specimens. In the 180-day period, Sealapex exhibited chronic inflammation in all the specimens and slight deposition of cementum over the material in only three cases. It is important to consider that Sealapex (2) presents lower proportion of calcium oxide $(\mathrm{CaO})$ than $\mathrm{PC}(8)$. The participation of calcium and hydroxyl ions in biological processes of tissue repair and antibacterial action has been well discussed (10-13). The justification for the present study is based on the indispensable understanding about the presence of $\mathrm{CaO}$, which has an important role on tissue biological response from its conversion into $\mathrm{CH}$, and the possible differences between the materials depending on the manufacturer and the location of the source of mineral extraction. Thus, the aims of this study were to characterize and to compare the presence of $\mathrm{CaO}$ on chemical composition of materials used for root perforation therapy.

\section{MATERIAL AND METHODS}

\section{Materials}

The materials used in this study were distributed in the following groups: Gray MTA-Angelus ${ }^{\circledR}$ (GMTA; Angelus, Londrina, PR, Brazil); White MTA-Angelus ${ }^{\circledR}$ (WMTA; Angelus, Londrina, PR, Brazil); Portland cement (PC; CP II-F-32; Cia. de Cimento Itaú, Itaú de Minas, MG, Brazil); Gray MTA-Angelus ${ }^{\circledR}$ (Angelus) with addition of $5 \% \mathrm{CaO}$ (Quimis; Mallinkrodt Inc., St. Louis, MO, USA); Gray MTA-Angelus ${ }^{\circledR}$ (Angelus) with addition of $10 \% \mathrm{CaO}$ (Quimis; Mallinkrodt Inc.); $\mathrm{CaO}$ (stardard) (Quimis; Mallinkrodt Inc.).

\section{Specimen Preparation}

The MTA cements were mixed according to the manufacturers' instructions. PC was mixed with distilled water at a water-to-cement ratio of $1: 3 . \mathrm{CaO}$ was added to the gray MTA by replacing 5 and $10 \%$ of the cement powder by weight.

Specimens were prepared by placing the tested materials into standard polyethylene tubes with an internal diameter of $3 \mathrm{~mm}$ and $3 \mathrm{~mm}$ in length. The tubes were placed on a glass slab $(75 \times 25 \times 1 \mathrm{~mm})$, slightly overfilled with the freshly prepared materials and then transferred to a chamber with $95 \%$ relative humidity and temperature of $37^{\circ} \mathrm{C}$ for a period corresponding to 3 times the manufacturer's recommended setting time. Three homogeneous specimens of each material were made.

\section{Scanning Electron Microscopy (SEM) and Energy Dispersive X-Ray Microanalysis (EDX)}

Morphological analysis of outer surface of root perforation sealers materials was performed using a scanning electron microscope (JSM-6610; Jeol Ltd., Tokyo, Japan) at $\times 500$ magnification, using an accelerating voltage of $20-25 \mathrm{kV}$ and a working distance of $15 \mathrm{~mm}$. The specimens were sprinkled on carbon double-sided tape over a metallic stub, critical-point dried and sputter-coated with gold-palladium (Bal-Tec AG, Balzers, Germany). EDX was performed with the detection-analysis-system NSS Spectral Analyses System 2.3 (Thermo Fisher Scientific, San Jose, CA, USA) to examine the elemental composition of the tested materials. One EDX spectrum was collected from the central region of each specimen under the following conditions: $25 \mathrm{kV}$ accelerating voltage, $110 \mu \mathrm{A}$ beam current, $10^{-6}$ Torr pressure (high-vacuum), $130 \times 130$ $\mu \mathrm{m}$ area of analysis at $\times 1,000$ magnification, $100 \mathrm{~s}$ acquisition time and $30-35 \%$ detector dead time. The elemental analysis (weight $\%$ and atomic $\%$ ) of samples was performed in nonstandard analysis mode, using PROZA(Phi-Rho-Z) correction method. The elemental maps were archived by NETCOUNTS method, with high resolution, using the same detection-analysis-system (NSS Spectral Analyses System 2.3).

\section{RESULTS}

A quantitative result of the chemical compounds and the main components of the tested materials is presented in Tables 1 and 2 . The following concentrations of $\mathrm{CaO}$ were found in samples: GMTA: 59.28\%; WMTA: 63.09\%; PC: $72.51 \%$; GMTA+5\%CaO: $63.48 \%$; GMTA $+10 \% \mathrm{CaO}: 67.55 \%$ (Table 1). EDX profile on 
gray and white MTAs revealed high peaks of calcium, bismuth and silicon, and traces of sodium, magnesium and aluminum, while high peaks of $\mathrm{Ca}$ and $\mathrm{Si}$ and absence of Bi was observed in PC (Fig. 1) The calcium levels found in the materials tested are described in Tables 2 and 3. Elemental mapping revealed the elements distributed throughout the morphological surface (Fig. 2). Calcium was strongly detected by such mapping.

\section{DISCUSSION}

Gray and white MTA, PC, and gray MTA added with 5 and $10 \% \mathrm{CaO}$ presented distinct morphological surfaces, with different $\mathrm{CaO}$ concentrations. Even with an increase of 5 and $10 \% \mathrm{CaO}$ in gray MTA, the $\mathrm{CaO}$ levels found were lower than those in the PC samples, but still within the specifications of the Brazilian Association of Technical Standards for clinker constitution of PC.

SEM and EDX have also been used in a previous study to evaluate the chemicals $(\mathrm{CaO})$ and the main components of materials (9). Elemental mapping permitted to reveal the elements distributed throughout the morphological surface, which may maintain direct contact with the tissue.

The Brazilian PC is constituted basically of tricalcium silicate $\left(3 \mathrm{CaO} \cdot \mathrm{SiO}_{2}\right)$, dicalcium silicate $(2 \mathrm{CaO}$. $\left.\mathrm{SiO}_{2}\right)$, tricalcium aluminate $\left(3 \mathrm{CaO} \cdot \mathrm{Al}_{2} \mathrm{O}_{3}\right)$, tetracalcium aluminoferrite $\left(4 \mathrm{CaO} \cdot \mathrm{Al}_{2} \mathrm{O}_{3} \cdot \mathrm{Fe}_{2} \mathrm{O}_{3}\right)$, free oxides $(\mathrm{CaO}$, $\mathrm{MgO}$ and alkali oxides), small amounts of calcium

Table 1. Main chemical compound (\%) of materials analyzed with energydispersive X-ray microanalysis (EDX).

\begin{tabular}{lcccccc}
\hline $\begin{array}{l}\text { Chemical } \\
\text { compound }\end{array}$ & GMTA & WMTA & PC & $\begin{array}{c}\text { GMTA } \\
+5 \% \mathrm{CaO}\end{array}$ & $\begin{array}{c}\text { GMTA } \\
+10 \% \mathrm{CaO}\end{array}$ & $\mathrm{CaO}$ \\
\hline $\mathrm{Na}_{2} \mathrm{O}$ & 0.72 & - & 1.40 & - & - & - \\
$\mathrm{MgO}$ & 4.38 & - & 1.01 & 3.62 & 3.53 & 0.78 \\
$\mathrm{Al}_{2} \mathrm{O}_{3}$ & 2.80 & 3.78 & 3.55 & 2.53 & 2.71 & - \\
$\mathrm{SiO}_{2}$ & 12.88 & 18.53 & 14.65 & 12.78 & 10.74 & - \\
$\mathrm{K}_{2} \mathrm{O}$ & 2.53 & - & 1.93 & 1.44 & 1.43 & - \\
$\mathrm{CaO}$ & 59.28 & 63.09 & 72.51 & 63.48 & 67.55 & 99.22 \\
$\mathrm{Fe}_{2} \mathrm{O}_{3}$ & 2.22 & - & 4.55 & 1.83 & 2.22 & - \\
$\mathrm{Bi}_{2} \mathrm{O}_{3}$ & 15.19 & 14.61 & $=$ & 14.31 & 11.81 & - \\
$\mathrm{PbO}$ & - & - & 0.40 & - & - & - \\
\hline
\end{tabular}

GMTA: Gray MTA. WMTA: White MTA. PC: Portland cement. CaO: calcium oxide. sulphate $\left(\mathrm{CaO} . \mathrm{SO}_{3} \cdot 2 \mathrm{H}_{2} \mathrm{O}\right)$, and some residues (14).

The $\mathrm{CaO}$ levels observed in the present study (Table 1) were compatible with those obtained in PC (73.60\%) (Birmingham, UK) and WMTA (66.90\%) (Angelus, Londrina, PR, Brazil) in a previous investigation (15). Asgary et al. (16) determined and compared the composition of a white MTA new toothcolored formula (Dentsply Tulsa Dental, Tulsa, OK, USA), an Iranian white Portland cement (Abyek White Cement, Abyek, Iran) and an Australian white Portland cement (Melcann White Cement, ACT, Australia). The percentage of $\mathrm{CaO}$ in these materials was $44.11 \%$, $52.76 \%$ and $53.99 \%$, respectively. Considering that MTA is composed of PC $(80 \%)$ and bismuth oxide $(20 \%)$, added for radiopacity $(5,17)$, and despite the possible differences between the materials depending on the manufacturer and the location of the source of mineral extraction, the results of $\mathrm{CaO}$ obtained in this study were also superior level of $\mathrm{CaO}$ present in PC. The results of $\mathrm{CaO}$ found by Asgary et al. (16) in relation to WMTA were well below those found in the present study. One of the probable reasons is the lower amount of PC in Dentsply's WMTA (16). The Angelus ${ }^{\circledR}$ WMTA used in the present study consists of $80 \%$ of PC clinker and $20 \%$ of bismuth oxide, thus offering a higher amount of PC (18). In each country, the cement industry produces materials standardized according to national normative agencies. In Brazil, it is manufactured the white PC, nonstructural, which is an ordinary PC, substantially free of iron oxide. This absence of iron oxide was also detected in the WMTA group, although, the manufacturer included this oxide as a component of the product. The alumina and iron oxide accelerate the start of the hydration reactions (initial grip) with the increase of their contents, for forming compounds that crystallize rapidly. The $\mathrm{CaO}$ that does not combine into clinker minerals is called $\mathrm{CaO}$ free (free lime), too much of which can cause delayed expansion. Because of the difficulty in determining the exact amount of free lime, the American Society for Testing and Materials ASTM-150 requires a soundness test that measures the volume stability of cement. The content of $\mathrm{CaO}$ free manufactured in Brazil is defined by the Brazilian Association of Technical Standards (NBR 5748) (14).

Camilleri (19) evaluated the biocompatibility of calcium sulpho- 
aluminate cement (CSA), calcium fluoro-aluminate cement (CFA) and glass ionomer cement (control, Ketac Molar) as new potential dental materials and their eluants by assessing cell viability. The major constituent was tricalcium silicate, which on hydration produced a silicate hydrate and $\mathrm{CH}$. Cell growth was poor when seeded in direct contact with the prototype cements. The glass ionomer cement stimulated cell growth after 1 day of cell contact. The eluted species for all the cements tested exhibited adequate cell viability in the early stages with reduced cell activity.
It is known that $\mathrm{CaO}$ is a basic oxide obtained by calcination of $\mathrm{CaCO}_{3}$, and represent important compound of $\mathrm{PC}$. Its hydration form $\mathrm{CH}$, and the chemical reaction between $\mathrm{CH}$ and carbon dioxide forms calcium carbonate (precipitation). The $\mathrm{CaO}$ free, uncombined, is rarely present in significant amounts in Portland cement updated.

The clinical discussion involving the $\mathrm{CaO}$ from MTA, and its transformation in $\mathrm{CH}$ consolidates knowledge already discussed in Endodontics. From the points raised above, it may be suggested that the
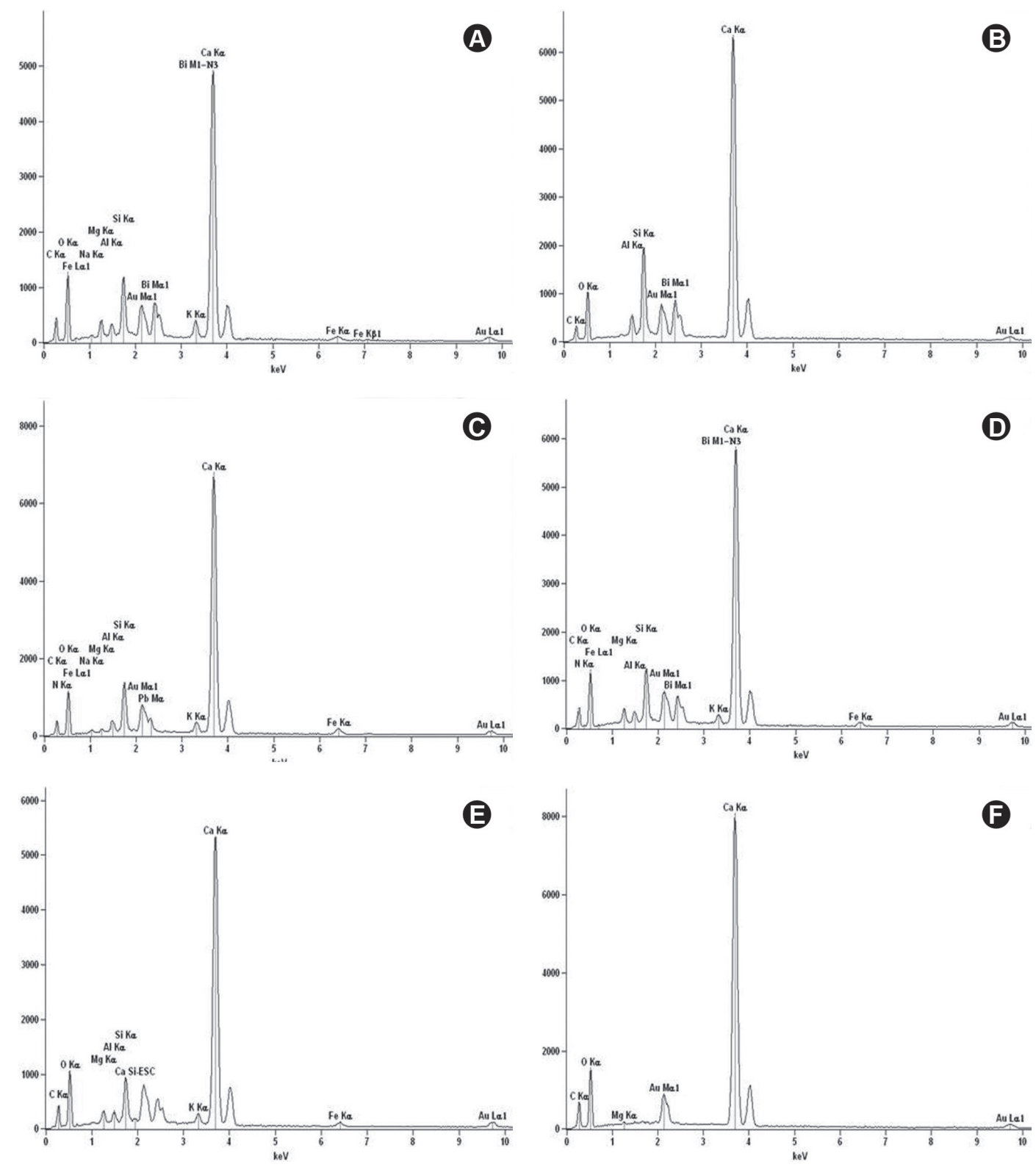

Figure 1. Representative EDX spectrum of the tested materials. A: GMTA. B: WMTA. C: PC. D: GMTA+\%CaO. E: GMTA+10\%CaO. $\mathrm{F}: \mathrm{CaO}$. 
greater amount of calcium and hydroxyl ions offered to the tissues, and the mechanical action as matrix (protecting against overfilling) justifies the use of $\mathrm{CH}$ pastes previously covering the root perforation area with MTA.

The properties of $\mathrm{CH}$ come from its dissociation into calcium and hydroxyl ions and the action of these ions on tissues and bacteria explains biological and antimicrobial properties of this substance (1013). Changes in the biological properties can also be understood by the chemical reactions, since $\mathrm{CH}$, in the presence of carbon dioxide, becomes calcium carbonate, and this product does not have the biological properties of $\mathrm{CH}$, such as the mineralizing capability. The release of hydroxyl ions from the pastes can be demonstrated by the release of calcium ions and hydroxyl ions and the molecular weight of $\mathrm{CH}$. Taking into account the molecular weight of $\mathrm{CH}$, which is 74.08 , using a rule of three, one can find the percentage of hydroxyl ions found in $\mathrm{CH}$, which is $45.89 \%$, while $54.11 \%$ corresponds to calcium ions (13).

Thus, it has been shown that $\mathrm{CH}$ induces the deposition of a hard tissue bridge on pulpal and periodontal connective tissue. The success of $\mathrm{CH}$ is due to its ionic effect observed by the chemical dissociation into calcium and hydroxyl ions. Its action on connective tissue (pulpal and periodontal tissues) revealed the ability to stimulate mineralization, from the significant

Table 2. Main components of root perforation sealer materials analyzed with energy-dispersive X-ray microanalysis (EDX).

\begin{tabular}{|c|c|c|c|c|c|c|}
\hline \multirow{2}{*}{ Element } & \multicolumn{2}{|c|}{ GMTA } & \multicolumn{2}{|c|}{ WMTA } & \multicolumn{2}{|c|}{$\mathrm{PC}$} \\
\hline & $\mathrm{wt} \%$ & at. $\%$ & wt $\%$ & at. $\%$ & $\mathrm{wt} \%$ & at. $\%$ \\
\hline $\mathrm{O}$ & 29.68 & 53.61 & 31.15 & 55.36 & 32.65 & 53.46 \\
\hline $\mathrm{Mg}$ & 2.64 & 3.14 & - & - & 0.61 & 0.66 \\
\hline $\mathrm{Al}$ & 1.48 & 1.59 & 2.00 & 2.11 & 1.88 & 1.82 \\
\hline $\mathrm{Si}$ & 6.02 & 6.20 & 8.66 & 8.77 & 6.85 & 6.39 \\
\hline K & 2.10 & 1.55 & - & - & 1.60 & 1.07 \\
\hline $\mathrm{Ca}$ & 42.37 & 30.56 & 45.09 & 31.99 & 51.82 & 33.87 \\
\hline $\mathrm{Fe}$ & 1.56 & 0.81 & - & - & 3.18 & 1.49 \\
\hline $\mathrm{Bi}$ & 13.63 & 1.88 & 13.11 & 1.78 & - & - \\
\hline $\mathrm{Na}$ & 0.53 & 0.67 & - & - & 1.04 & 1.19 \\
\hline $\mathrm{Pb}$ & - & - & - & - & 0.37 & 0.05 \\
\hline
\end{tabular}

GMTA: Gray MTA. WMTA: White MTA. PC: Portland cement. $\mathrm{CaO}$ : calcium oxide. involvement of alkaline phosphatase and fibronectin (1013,20). Sarkar et al. (21) characterized the interactions of MTA with a synthetic tissue fluid composed of a neutral phosphate buffer saline solution and root canal dentin in extracted human teeth using inductively coupled plasma-atomic emission spectroscopy, SEM, EDX, and X-ray diffraction. MTA exposed to synthetic tissue fluid at $37^{\circ} \mathrm{C}$ released its metallic constituents and produced precipitates with a composition and structure similar to that of hydroxyapatite $\left[\mathrm{Ca}_{10}\left(\mathrm{PO}_{4}\right)_{6}(\mathrm{OH})_{2} \mathrm{HA}\right]$. Endodontically prepared teeth filled with MTA and stored in synthetic tissue fluid at $37^{\circ} \mathrm{C}$ for 2 months produced at the dentin wall an adherent interfacial layer that resembled hydroxyapatite in composition. The $\mathrm{Ca}$, dominant ion released from MTA, reacts with phosphates in synthetic tissue fluid, yielding hydroxyapatite. The dentin-MTA interfacial layer results from a similar reaction. The sealing ability, biocompatibility, and dentinogenic activity of MTA is attributed to these physicochemical reactions. Torabinejad et al. (18) by electron probe microanalysis of MTA powder reported that calcium and phosphorous are the main ions present in this material. Because these ions are also the main components of dental hard tissues, MTA may have a biocompatible behavior when used in contact with cells and tissues. Vasconcelos et al. (22) evaluated the $\mathrm{pH}$ and calcium ion release of several materials used for root-end filling and perforation repair. Gray ProRoot MTA, gray MTA-Angelus, white MTA-Angelus, and CPM were compared with 2 experimental ones: MTA-exp, also

Table 3. Main components of experimental materials analyzed by energy-dispersive X-ray microanalysis (EDX).

\begin{tabular}{|c|c|c|c|c|c|c|}
\hline \multirow[t]{2}{*}{ Element } & \multicolumn{2}{|c|}{$\begin{array}{c}\text { GMTA } \\
+5 \% \mathrm{CaO}\end{array}$} & \multicolumn{2}{|c|}{$\begin{array}{c}\text { GMTA } \\
+10 \% \mathrm{CaO}\end{array}$} & \multicolumn{2}{|c|}{$\mathrm{CaO}$} \\
\hline & $\mathrm{wt} \%$ & at. $\%$ & $\mathrm{wt} \%$ & at. $\%$ & $\mathrm{wt} \%$ & at. $\%$ \\
\hline $\mathrm{O}$ & 29.82 & 53.82 & 29.80 & 53.28 & 28.62 & 50.00 \\
\hline $\mathrm{Mg}$ & 2.18 & 2.59 & 2.13 & 2.51 & 0.47 & 0.54 \\
\hline $\mathrm{Al}$ & 1.34 & 1.44 & 1.43 & 1.52 & - & - \\
\hline $\mathrm{Si}$ & 5.98 & 6.14 & 5.02 & 5.12 & - & - \\
\hline $\mathrm{K}$ & 1.20 & 0.88 & 1.19 & 0.87 & - & - \\
\hline $\mathrm{Ca}$ & 45.37 & 32.69 & 48.28 & 34.46 & 70.92 & 49.46 \\
\hline $\mathrm{Fe}$ & 1.28 & 0.66 & 1.55 & 0.80 & - & - \\
\hline $\mathrm{Bi}$ & 12.84 & 1.77 & 10.60 & 1.45 & - & - \\
\hline
\end{tabular}

GMTA: Gray MTA; CaO: calcium oxide. 
based in Portland cement with a modified mixing liquid, and MBPc, an epoxy-resin based cement containing $\mathrm{CH}$. After 3, 24, 72, and $168 \mathrm{~h}$, the water in which each sample had been immersed was tested to determine the $\mathrm{pH}$ and calcium ion release. All the analyzed materials showed alkaline $\mathrm{pH}$ and capacity to release calcium ions; however, a tendency of reduction of these characteristics was noted for all the analyzed materials, except for the MBPc, which showed a slight increase of $\mathrm{pH}$ among the 3 initial periods. The results suggest that all materials investigated presented an alkaline $\mathrm{pH}$ and ability of release of calcium ions.

In addition, the mechanism of action of $\mathrm{CH}$ on bacteria can be explained by the influence of $\mathrm{pH}$ on growth, metabolism and bacterial cell division. The elevated $\mathrm{pH}$ of $\mathrm{CH}$, with values reaching 12.6 , is observed to the great release of hydroxyl ions, which are capable of altering the integrity of the bacterial cytoplasmic membrane through the toxic effects generated during the transfer of nutrients or through the destruction of the phospholipids of unsaturated fatty acids. The influence of $\mathrm{pH}$ alters the integrity of the
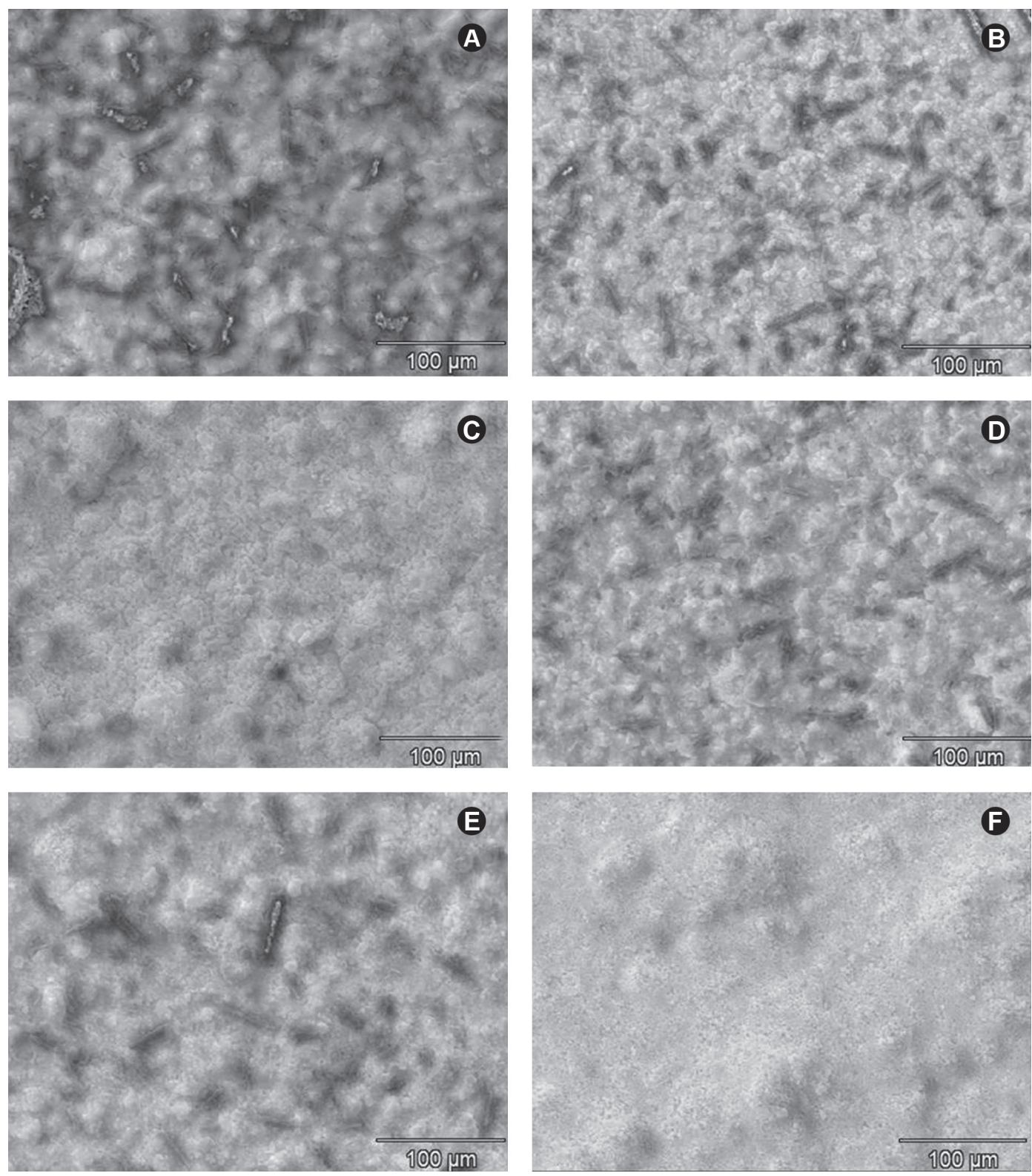

Figure 2. EDX elemental maps of calcium distribution throughout the morphological surface of tested materials: A: GMTA. B: WMTA. C: PC. D: GMTA+5\%CaO. E: GMTA+10\%CaO. F: CaO. 
cytoplasmic membrane by biochemical injury to organic components (proteins, phospholipids) and transport of nutrients. The maintenance of a high concentration of hydroxyl ions can change the enzymatic activity and promote its inactivation (10-13).

Calcium salts deposition in rat connective tissue after the implantation of MTA, Sealapex, CRCS, Sealer 26, and the experimental material, Sealer Plus was reported by Holland et al. (11). CRCS was the only material that did not exhibit any kind of calcified structure, which was observed with the other materials. All the other studied materials exhibited deposition of mineralized structures birefringent to polarized light or Von Kossa-positive, with some quantitative differences. The results of MTA agree with the findings reported previously, which indicated similar results for MTA and $\mathrm{CH}$. The $\mathrm{CaO}$ could react with tissue fluids to form $\mathrm{CH}$. The birefringent granulations observed next to MTA and into the dentin wall tubules are probably calcite crystals originating from the reaction of the calcium from the material with the carbon dioxide from the connective tissue.

These granulations are formed by the reaction of the $\mathrm{CH}$ with the carbonic gas of the tissue. The same granulations were described by Seux et al. (23). These authors verified an accumulation of fibronectin, a glycoprotein, in intimate contact with these calcite crystals, in a culture medium without cells. When pulp cells were placed in contact with this environment, there was formation of cells with the morphological aspect of odontoblasts. In the absence of calcite granulations there was only proliferation of fibroblasts. These findings constituted strong evidence of the role of the calcite granulations and fibronectin as the beginning of the formation of a hard tissue barrier. Similarity, it has been shown between the results of $\mathrm{CH}$ and MTA in subcutaneous tissue of rats. Both materials determined the formation of calcite granulations and a subjacent hard tissue bridge (3). Mizuno and Banzai (24) investigated the effect of calcium ions on the dental pulp cells and the mechanism of dentine bridge formation by $\mathrm{CH}$. Calcium ion release from $\mathrm{CH}$ stimulates fibronectin synthesis in dental pulp cells. Fibronectin might induce the differentiation of dental pulp cells to mineralized tissue forming cells that are the main cells to form dentin bridges, via direct contact. The expression of extracellular matrix glycoproteins (fibronectin and tenascin) was determined by immunohistochemical technique following direct pulp capping with $\mathrm{CH}$ (25).
The results showed expression of both glycoproteins during pulp healing process.

The participation of calcium and hydroxyl ions from $\mathrm{CH}$ in pulpal and periodontal tissue healing process is well established. However, the amount of calcium and hydroxyl ions needed to tissues to trigger the stimulus of enzymatic induction and healing process should be further investigated. One should take into consideration the important indication of the MTA in cases of root perforation, considering the clinical and pathological conditions, the biological, physical and chemical characteristics, as well as the ease of handling. In conclusion, the materials tested in the present study showed different $\mathrm{CaO}$ concentrations. Even with an increase of 5 and $10 \% \mathrm{CaO}$ in gray MTA, the levels of $\mathrm{CaO}$ in MTA samples were lower than those found in PC.

\section{RESUMO}

A perfuração do canal radicular representa uma complicação indesejável que sugere um prognóstico desfavorável. Os objetivos deste estudo foram caracterizar e comparar a presença de óxido de cálcio $(\mathrm{CaO})$ na composição química de vários materiais utilizados no tratamento de perfurações radiculares. Foram analisados os materiais MTA cinza e branco, cimento Portland e na tentativa de se observar o aumento nos valores de $\mathrm{CaO}$ foram testados MTA cinza $+5 \%$ de óxido de cálcio, MTA cinza $+10 \%$ de óxido de cálcio e o $\mathrm{CaO}$ (padrão). Foram preparados 18 tubos de polietileno com diâmetro interno e comprimento de $3 \mathrm{~mm}$. Estes foram preenchidos e depois transferidos para uma estufa com umidade relativa de $95 \%$ e temperatura de $37^{\circ} \mathrm{C}$. Os compostos químicos (principalmente o óxido de cálcio) e os principais componentes foram avaliados por espectrometria de dispersão de raios-X (EDX). A análise por EDX revelou as seguintes concentrações de CaO: 59,28\% no MTA cinza; $63,09 \%$ no MTA branco; $72,51 \%$ no cimento Portland; $63,48 \%$ no MTA cinza $+5 \%$ de $\mathrm{CaO} ; 67,55 \%$ no MTA cinza $+10 \%$ de $\mathrm{CaO}$. Os materiais testados apresentaram diferentes concentrações de $\mathrm{CaO}$. Mesmo com o acréscimo de $\mathrm{CaO}$ nas concentrações de 5 e $10 \%$ ao MTA cinza, os valores de $\mathrm{CaO}$ foram inferiores aos observados no cimento Portland.

\section{ACKNOWLEDGEMENTS}

The authors deny any conflicts of interest related to this study. This study was supported in part by grants from the National Council for Scientific and Technological Development (CNPq grants 306394/2011-1 to C.E.). The authors acknowledge Tatiane Oliveira dos Santos (Institute of Physics, Federal University of Goiás, GO, Brazil) for the support and technical assistance in the microscopic assays.

\section{REFERENCES}

1. Pitt Ford TR, Torabinejad M, McKendry DJ, Hong CU, Kariyawasam SP. Use of mineral trioxide aggregate for repair of 
furcal perforations. Oral Surg Oral Med Oral Pathol 1995;79:756762.

2. Holland R, Otoboni-Filho JA, Souza V, Nery MJ, Bernabe PFE, Dezan-Junior E. Mineral trioxide aggregate repair of lateral root perforations. J Endod 2001;4:281-284.

3. Holland R, de Souza V, Nery MJ, Otoboni Filho JA, Bernabé PF, Dezan Júnior E. Reaction of rat connective tissue to implanted dentin tubes filled with mineral trioxide aggregate or calcium hydroxide. J Endod 1999;25:161-166.

4. Holland R, de Souza V. Ability of a new calcium hydroxide root canal filling material to induce hard tissue formation. J Endod 1985; 11:535-543.

5. Torabinejad M, Watson TF, Pitt Ford TR. Sealing ability of a mineral trioxide aggregate when used as a root end filling material. J Endod 1993;19:591-595.

6. Parirokh M, Torabinejad M. Mineral trioxide aggregate: A comprehensive literature review - Part III: Clinical applications, drawbacks, and mechanism of action. J Endod 2010;36:400-413.

7. Camilleri J, Pitt Ford TR. Mineral trioxide aggregate: a review of the constituents and biological properties of the material. Int Endod J 2006;39:747-754.

8. Estrela C, Bammann LL, Estrela CRA, Silva RS, Pecora JD. Antimicrobial and chemical study of MTA, Portland cement, calcium hydroxide paste, Sealapex and Dycal. Braz Dent J 2000;11:3-9.

9. Camilleri J, Montesin FE, Brady K, Sweeney R, Curtis RV, Ford TR. The constitution of mineral trioxide aggregate. Dent Mater 2005;21:297-303.

10. Holland R, de Souza V, Nery MJ, Faraco Júnior IM Bernabé PFE, Otoboni Filho JA, et al.. Reaction of rat connective tissue to implanted dentin tube filled with mineral trioxide aggregate, Portland cement or calcium hydroxide. Braz Dent J 2001;12:3-8.

11. Holland R, de Souza V, Nery MJ, Bernabé PFE, Filho JA, DezanJunior E, et al.. Calcium salts deposition in rat connective tissue after the implantation of calcium hydroxide-containing sealers. J Endod 2002;28:173-176.

12. Estrela C, Sydney GB, Bammann LL, Felippe-Jr O. Mechanism of action of calcium and hydroxyl ions of calcium hydroxide on tissue and bacteria. Braz Dent J 1995;6:85-90.

13. Estrela C, Holland R. Calcium hydroxide. In: Estrela C. Endodontic Science 2nd ed. São Paulo Artes Médicas; 2009. p. 746-821.

14. Oliveira HM. Portland cement. In: Bauer LAF. Construction Materials. 5 ed. LCT: Rio de Janeiro; 2000. p. 35-62.
15. Camilleri J, Kralj P, Veber M, Sinagra E. Characterization and analyses of acid-extractable and leached trace elements in dental cements. Int Endod J 2012;45:737-743.

16. Asgary S, Parirokh M, Eqhbal MJ, Brink F. A comparative study of white mineral trioxide aggregate and white Portland cements using X-ray microanalysis. Aust Endod J 2004;30:89-92.

17. Torabinejad M, Hong CU, McDonald F, Pitt Ford TR. Physical and chemical properties of a new root-end filling material. J Endod 1995;21:349-353.

18. Duarte MAH, Minotti PG, Rodrigues CT, Zapata RO, Bramante $\mathrm{CM}$, Tanomaru-Filho M, et al.. Effect of different radiopacifying agents on the physicochemical properties of white Portland cement and white mineral trioxide aggregate. J Endod 2012;38:394-397.

19. Camilleri J. The biocompatibility of modified experimental Portland cements with potential for use in dentistry. Int Endod J 2008;41:1107-1114.

20. Bal C, Oztas N, Cincik M, Baris E. Immunolocalizatíon of fibronectin during reparative dentinogenesis in rat molar teeth after pulp capping with mineral trioxide aggregate or calcium hydroxide. N Y State Dent J 2011;77:36-42.

21. Sarkar NK, Caicedo R, Ritwik P, Moiseyeva R, Kawashima I. Physicochemical basis of the biologic properties of mineral trioxide aggregate. J Endod 2005;31:97-100.

22. Vasconcelos BC, Bernardes RA, Cruz SML, Duarte MAH, Padilha $\mathrm{PM}$, Bernardineli $\mathrm{N}$, et al.. Evaluation of $\mathrm{pH}$ and calcium ion release of new root-end filling materials. Oral Surg Oral Med Oral Pathol Oral Radiol Endod 2009;108:135-139.

23. Seux D, Couble ML, Hartmann DJ, Gauthier JP, Magloire H. Odontoblast-like cytodifferentiation of human dental pulp cells in vitro in the presence of a calcium hydroxide-containing cement. Arch Oral Biol 1991;36:117-128.

24. Mizuno M, Banzai Y. Calcium ion release from calcium hydroxide stimulated fibronectin gene expression in dental pulp cells and the differentiation of dental pulp cells to mineralized tissue forming cells by fibronectin. Int Endod J 2008;41:933-938.

25. Piva E, Tarquinio SBC, Demarco FF, Silva AF, Araujo VC. Immunohistochemical expression of fibronectin and tenascin after direct pulp capping with calcium hydroxide. Oral Med Oral Pathol Oral Radiol Endod 2006;102:e66-e71.

Received March 15, 2012 Accepted October 31, 2012 